\title{
Chromophoric dissolved organic matter in experimental mesocosms maintained under different $\mathrm{pCO}_{2}$ levels
}

\author{
Emma Rochelle-Newall ${ }^{1,5, *}$, Bruno Delille ${ }^{2}$, Michel Frankignoulle ${ }^{2}$, \\ Jean-Pierre Gattuso ${ }^{1}$, Stéphan Jacquet ${ }^{3}$, Ulf Riebesell ${ }^{4}$, Anja Terbruggen ${ }^{4}$, \\ Ingrid Zondervan ${ }^{4}$
}

\author{
${ }^{1}$ Laboratoire d'Océanographie, CNRS-Université de Paris 6, BP 28, 06234 Villefranche-sur-mer Cedex, France \\ ${ }^{2}$ Unité d'Océanographie Chimique, Université de Liege, 4000 Liège, Belgium \\ ${ }^{3}$ UMR CARRTEL, Station INRA d'Hydrobiologie Lacustre, 74203 Thonon les Bains Cedex, France \\ ${ }^{4}$ Alfred Wegener Institute for Polar and Marine Research, 27515 Bremerhaven, Germany \\ ${ }^{5}$ Present address: Centre IRD de Noumea, BP A5, 98848 Noumea Cedex, New Caledonia
}

\begin{abstract}
Chromophoric dissolved organic matter (CDOM) represents the optically active fraction of the bulk dissolved organic matter (DOM) pool. Recent evidence pointed towards a microbial source of CDOM in the aquatic environment and led to the proposal that phytoplankton is not a direct source of CDOM, but that heterotrophic bacteria, through reprocessing of DOM of algal origin, are an important source of CDOM. In a recent experiment designed at looking at the effects of elevated $\mathrm{pCO}_{2}$ on blooms of the coccolithophorid alga Emiliania huxleyi, we found that despite the 3 different $\mathrm{pCO}_{2}$ levels tested $(190,414$ and $714 \mathrm{ppm})$, no differences were observed in accumulation of CDOM over the $20 \mathrm{~d}$ of incubation. Unlike previous mesocosm experiments where relationships between CDOM accumulation and bacterial abundance have been observed, none was observed here. These results provide some new insights into the apparent lack of effect of $\mathrm{pCO}_{2}$ on $\mathrm{CDOM}$ accumulation in surface waters, and question the previously proposed mechanisms and rates of CDOM production in natural phytoplankton blooms.
\end{abstract}

KEY WORDS: CDOM $\cdot$ DOC $\cdot$ Mesocosms $\cdot$ Viruses $\cdot$ Cyanobacteria $\cdot$ Heterotrophic bacteria $\cdot \mathrm{CO}_{2}$

\section{INTRODUCTION}

The absorption of light in the ultra-violet (UV) and visible wavelengths by chromophoric (or coloured) dissolved organic matter (CDOM) suggests that these compounds can have important optical and ecological impacts in the water column, particularly in the surface layers. Despite this, we still do not have a good understanding of the processes that affect the production and removal of CDOM in the surface ocean (Blough \& Del Vecchio 2002). Although recent work has proposed that heterotrophic bacteria are the source of CDOM (Nelson et al. 1998, Rochelle-Newall et al. 1999), the role of phytoplankton and other organisms in its production remains unclear or unknown. As phytoplankton is the major source of fixed carbon in the ocean, it is probable that it plays an indirect role in the production of CDOM (Rochelle-Newall \& Fisher 2002a). However, whether the dissolved organic matter (DOM) precursors of CDOM are released actively by the phytoplankton during normal cellular processes, or from cell rupture caused by viral attack, remains unknown.

The partial pressure of $\mathrm{CO}_{2}\left(\mathrm{pCO}_{2}\right)$, in the atmosphere has increased by ca. $30 \%$ since 1880 (370 vs $280 \mu \mathrm{atm})$ and is likely to continue to increase in the 
near future (IPCC 2001). A doubling of the pre-industrial value may be reached by 2065 . This increase also occurs in the surface oceans, which are, on average, in equilibrium with the atmosphere. Some oceanic biogeochemical processes, such as calcification (Gattuso et al. 1999, Riebesell et al. 2000) and primary production (Hein \& Sand-Jensen 1997), will probably be affected, but no information is available on the response of the reservoirs of DOC and CDOM, nor on the processes that control them. If increased $\mathrm{pCO}_{2}$ in the oceans leads to an increase in CDOM in the surface ocean, then this increase could lead to a decrease in the amount of light in the upper water column and so enhance the shading of phytoplankton (Arrigo \& Brown 1996). Conversely, a decrease in CDOM might lead to increased water penetration of UV radiation, which could lead to an increase in UV-mediated damage to organisms in the surface waters (Williamson et al. 1996). In addition to this, if the expected increase in $\mathrm{pCO}_{2}$ results in a change in the rates of production and release of organic carbon by phytoplankton, there may also be important impacts upon the microbial loop.

Emiliania huxleyi is a coccolithophorid phytoplanktonic alga that is ubiquitous in the world's oceans. It can form large blooms that are easily detectable by satellite imagery, and their production of calcium carbonate coccoliths can affect the inorganic carbon concentration of surface waters (Robertson et al. 1994) and play an important role in the transport of $\mathrm{CaCO}_{3}$ to the deep ocean (Milliman \& Droxler 1996). Here we present results from a mesocosm experiment that was designed to investigate the effects of increased $\mathrm{pCO}_{2}$ on the carbonate chemistry and biogeochemical cycling during a bloom of E. huxleyi and on the potential effects of increased $\mathrm{pCO}_{2}$ on the dynamics of CDOM accumulation. Our aim was to determine whether increased $\mathrm{pCO}_{2}$ leads to an increase in CDOM absorption in the mesocosms.

\section{MATERIALS AND METHODS}

The detailed set up and maintenance of the mesocosms is described in Engel et al. (unpubl.) and the changes in carbonate chemistry, primary production and calcification are described in Delille et al. (unpubl.). Briefly, 9 mesocosms were maintained under 3 different $\mathrm{pCO}_{2}$ levels at the Large Scale Facility of the Marine Biological Field Station of the University of Bergen, Norway, from 31 May to 25 June 2001. The mesocosms were bags of $2 \mathrm{~m}$ diameter, $4 \mathrm{~m}$ in depth and $11 \mathrm{~m}^{3}$ in volume. Each mesocosm was covered by a tent constructed of a polyethylene film that permitted the transmission of $95 \%$ of the light, and water in the mesocosms was gently mixed throughout the experi- ment by means of a controlled air pump system. The 3 carbon dioxide concentrations were selected to approximately simulate the $\mathrm{pCO}_{2}$ concentrations observed in the pre-industrial era (190 ppm), the present $(414 \mathrm{ppm})$ and those expected to be observed in 2100 (714 ppm; IPCC's 'business as usual' scenario IS92a, IPCC 2001).

The bags were filled on 31 May with fjord seawater $\left(\right.$ salinity $=31$, temperature $\left.=9^{\circ} \mathrm{C}\right)$. On 6 June (Day 0), inorganic nutrients were added at an N:P ratio of 30:1 in order to promote phosphate limitation, as this is known to stimulate the blooming of Emiliania huxleyi in this area (Egge \& Heimdal 1994). The final concentrations of $\mathrm{PO}_{4}$ and $\mathrm{NO}_{3}+\mathrm{NO}_{2}$ after nutrient addition were 0.5 and $15 \mu \mathrm{M}$, respectively.

Samples for DOC analysis were collected in combusted $\left(450^{\circ} \mathrm{C}\right.$ for 4 to $\left.5 \mathrm{~h}\right)$ glass ampoules after filtration through combusted Whatman GF/F filters. The $10 \mathrm{ml}$ samples were poisoned immediately upon filtration with $12 \mu \mathrm{l} 85 \% \mathrm{H}_{3} \mathrm{PO}_{4}$ and flame-sealed. Samples were stored in the dark until analysis. DOC measurement was performed using high temperature combustion on a Shimadzu TOC-5000 total organic carbon analyser. A 4-point calibration curve was constructed for each measurement day using potassium phthalate standards prepared fresh in UV-treated Milli-Q water. The standards covered the range 0 to $200 \mu \mathrm{M}$ C. In order to assess the instrument blank we used 2 external standards (Certified Reference Standards) obtained from the Hansell Laboratory, RSMAS, University of Miami. The machine blank was between 10 and $12 \mu \mathrm{M} \mathrm{C}$ for all samples, and was subtracted from the measurements. All DOM concentrations reported are the average of 3 injections from each sample.

Samples for CDOM were also collected in combusted $\left(450^{\circ} \mathrm{C}\right.$ for 4 to $\left.5 \mathrm{~h}\right) 20 \mathrm{ml}$ glass ampoules after sequential filtration through combusted Whatman GF/F filters and $0.2 \mu \mathrm{m}$ filters (Gelman Supor). The samples were flame sealed immediately after collection and stored frozen $\left(-18^{\circ} \mathrm{C}\right)$ pending analysis. The absorption spectra of the samples were measured on a Perkin Elmer LS 19 spectrophotometer using a $10 \mathrm{~cm}$ quartz cell and a Milli-Q water blank. All spectra are blank subtracted. $S$, the slope parameter, was calculated using the method of Stedmon et al. (2000).

Phytoplankton, picocyanobacterial and viral abundance were counted on a FacsCalibur flow cytometer (Becton Dickinson) following Jacquet et al. (2002). Briefly, the algae were analyzed from fresh samples at a high rate $\left(\sim 70 \mu \mathrm{min}^{-1}\right)$, with the addition of $1 \mu \mathrm{m}$ fluorescent beads (Molecular Probes). Autotrophic groups were discriminated on the basis of their forward or right angle light scatter (FALS, RALS) and chlorophyll (and phycoerythrin for Synechococcus populations) fluorescence. Virus enumeration was 


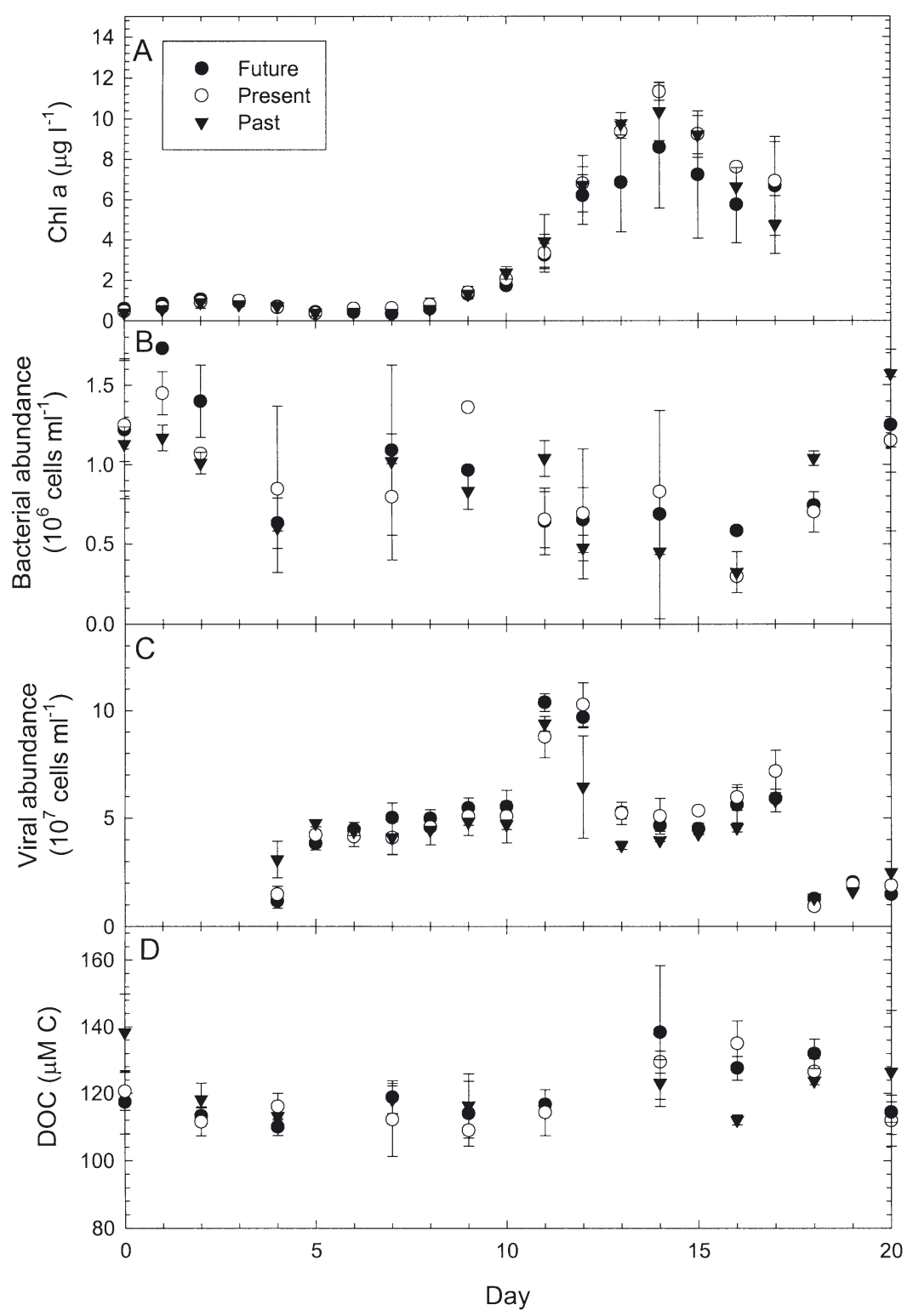

Fig. 1. Dynamics of (A) chl a concentration, (B) bacterial abundance (BA), (C) viral abundance (VA), and (D) dissolved organic carbon concentration (DOC). ๑: future (high $\mathrm{pCO}_{2}$ treatment); O: present (present $\mathrm{pCO}_{2}$ levels); $\nabla$ : past (glacial $\mathrm{pCO}_{2}$ levels)

performed on fixed (with glutaraldehyde, $0.5 \%$ final concentration) and frozen (using liquid nitrogen) samples. Once thawed at $37^{\circ} \mathrm{C}$, samples were diluted in TE (Tris-EDTA, $\mathrm{pH}=8$ ) buffer 10 to 100 times and heated for $10 \mathrm{~min}$ at $80^{\circ} \mathrm{C}$ after staining with the DNA dye SYBR Green I (1/10 000 final concentration, Molecular Probes). Analysis was performed at medium rate $\left(\sim 30 \mu \mathrm{l} \mathrm{min}{ }^{-1}\right)$. Viruses were distinguished on the basis of their RALS vs green DNA-dye fluorescence. Listmode files were analyzed using CYTOWIN (Vaulot 1989).
Bacterial abundance was measured by a direct count method using epifluorescent microscopy and DAPIstained samples (Porter \& Feig 1980). Samples $(10 \mathrm{ml})$ were preserved with $0.2 \mu \mathrm{m}$ pore-size filtered borax-buffered formalin ( $2 \%$ final concentration) and stored at $4^{\circ} \mathrm{C}$ in the dark. Within $36 \mathrm{~h}$, $10 \mathrm{ml}$ samples were stained with $0.2 \mu \mathrm{m}$ filtered DAPI solution for 10 min before filtering onto a black $0.2 \mu \mathrm{m}$ pore-size Osmonics filter. Filters were mounted on slides with non-fluorescent immersion oil and stored frozen until enumeration. For enumeration, at least 20 to 30 randomly selected microscope fields on each filter were counted with a Zeiss microscope at a magnification of $1250 \times$.

As CDOM was only measured in 6 of the 9 mesocosms, 2 from each treatment, the average values and standard deviations from these duplicate treatments are reported for all parameters.

\section{RESULTS}

The addition of inorganic nutrients was followed by a significant increase in algal biomass in all of the mesocosms, with the peak of chl a occurring on Days 13 and 14 (Fig. 1A). Bacterial abundance (BA) was initially high $\left(>1 \times 10^{6}\right.$ cells ml $\left.{ }^{-1}\right)$ and thereafter began to decrease, reaching an abundance of $<0.6 \times 10^{6}$ cells ml $^{-1}$ on Day 4. BA then increased between Days 6 and 9 in all 3 treatments, declined to a minimum of $<0.5 \times 10^{6}$ cells $\mathrm{ml}^{-1}$ by Day 16 and then began to increase to a final value close to that of Day 0 (Fig. 1B). Viral abundance (VA) showed a different pattern, with initial concentrations relatively low $\left(<1 \times 10^{6}\right.$ particles $\mathrm{ml}^{-1}$; Fig. 1C). It subsequently increased in all mesocosms by a factor of 100 to more than $1 \times 10^{8}$ particles $\mathrm{ml}^{-1}$ by Day 12 , and thereafter rapidly decreased in abundance to almost initial concentrations by Day 20 .

The concentration of dissolved organic carbon (DOC) was initially low in all mesocosms (average of $125 \mu \mathrm{M} \mathrm{C} \mathrm{C}_{i}$ Fig. 1D). DOC concentration remained constant, with some small-scale heterogeneity until Day 11. Between Days 11 and 14 (peak of the bloom), concentration increased in all treatments and then decreased to levels similar to the initial concentrations by Day 20 . 


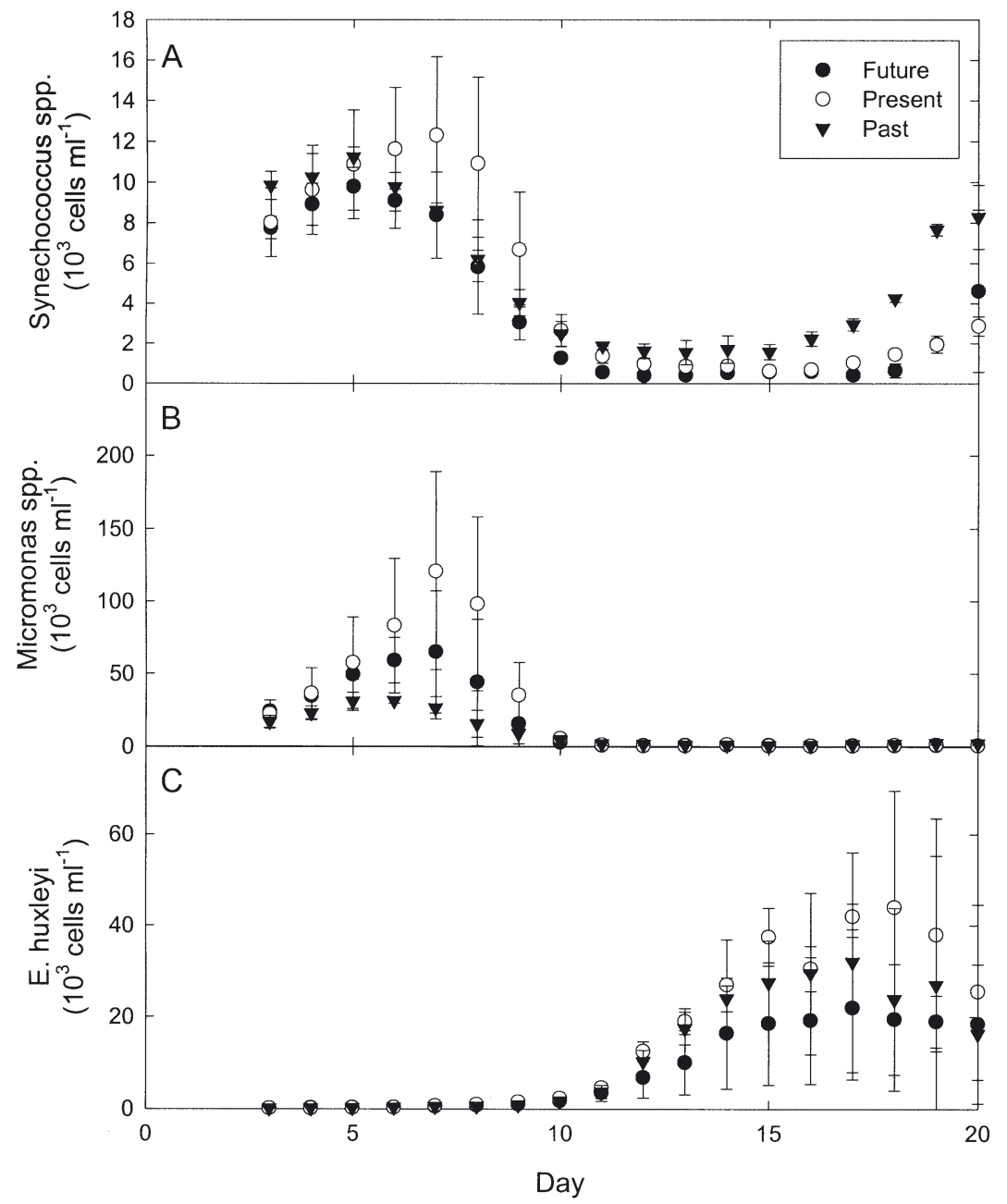

Fig. 2. Abundance of (A) picocyanobacteria (Synechococcus spp.), (B) Micromonas spp., and (C) Emiliania huxleyi during the experiment. See Fig. 1 legend for details

There were 2 main algal blooms in the mesocosms. The first, the picocyanobacteria Synechococcus, bloomed early on in the experiment, peaking on Days 5 to 7 (Fig. 2A). A second, smaller, bloom was evident in the later part of the experiment, but cell numbers were ca. $50 \%$ lower $\left(5 \times 10^{3}\right.$ vs $10 \times 10^{3}$ cells ml $^{-1}$ for the second and first blooms, respectively). During this initial phase of the experiment, there was also a bloom of Micromonas sp., peaking in abundance on Days 7 to 8 (26 to $120 \times 10^{3}$ cells ml ${ }^{-1}$ ) and thereafter declining to a concentration of $<5 \times 10^{3}$ cells $\mathrm{ml}^{-1}$ by Day 10 (Fig. 2B). Following the crash of the first picocyanobacterial and the Micromonas spp. blooms, the abundance of Emiliania huxleyi began to increase. From an initial concentration on Day 10 of 1.75 to $2.3 \times 10^{3}$ cells ml ${ }^{-1}$, abundance increased to a maximum value of 22 to $42 \times$ $10^{3}$ cells $\mathrm{ml}^{-1}$ by Days 15 and 16 (Fig. 2C), and thereafter began to decline slightly to concentrations of 16 to $23 \times 10^{3}$ cells $\mathrm{ml}^{-1}$ by Day 20 .
CDOM absorption, measured at $355 \mathrm{~nm}$, was similar in all treatments at the beginning of the experiment (Fig. 3A). Although variability between the replicate mesocosms was high, resulting in correlation coefficients that were not significantly different from zero $(p>0.05)$, there was a general trend of decreasing CDOM absorption in all 3 treatments until Day 10, after which time absorption began to increase. The slope parameter ( $S$; Fig. 3B), which expresses the exponential rate of decrease of absorption with increasing wavelength, exhibited an increasing trend over the first $10 \mathrm{~d}$ of the experiment. In the second half of the experiment, between Days 14 and 20, $S$ tended to decrease in all treatments. However, as with CDOM absorption, the correlation coefficients were not significantly different from zero ( $p$ > 0.05 ) for either the first or second parts of the experiment. CDOM and $S$ were correlated in the present and past treatments (simple linear correlation, $\mathrm{r}^{2}=0$. $64, \mathrm{p}<0.01 ; \mathrm{r}^{2}=0.54, \mathrm{p}<0.05$, respectively) and in the data set as a whole $\left(\mathrm{r}^{2}=\right.$ 0.63 , p < 0.05), with higher $S$-values observed when absorption was higher (Fig. 3C). There was no significant ( $\mathrm{p}>$ $0.05)$ correlation between DOC and CDOM absorption when either the data within each treatment were compared or when the entire dataset was considered. This was also the case for the correlation between DOC and $S$ (p > 0.05; data not shown). CDOM absorption was neither correlated with bacterial abundance nor with picocyanobacterial or Emiliania huxleyi abundance ( $\mathrm{p}>0.05$; data not shown).

\section{DISCUSSION}

The initial goal of this part of the experiment was to examine the potential effects of increased $\mathrm{pCO}_{2}$ on the accumulation of CDOM during an Emiliania huxleyi bloom. However, there did not appear to be any obvious effects on the accumulation of CDOM during the period of the experiment. There are several reasons to explain this apparent lack of effect. No large differences between treatments in terms of either photosynthesis or respiration were observed (Delille et al. in prep), nor were there large differences in DOC accumulation (Engel et al. 2004), meaning that it is improbable that large differences would have been observed 

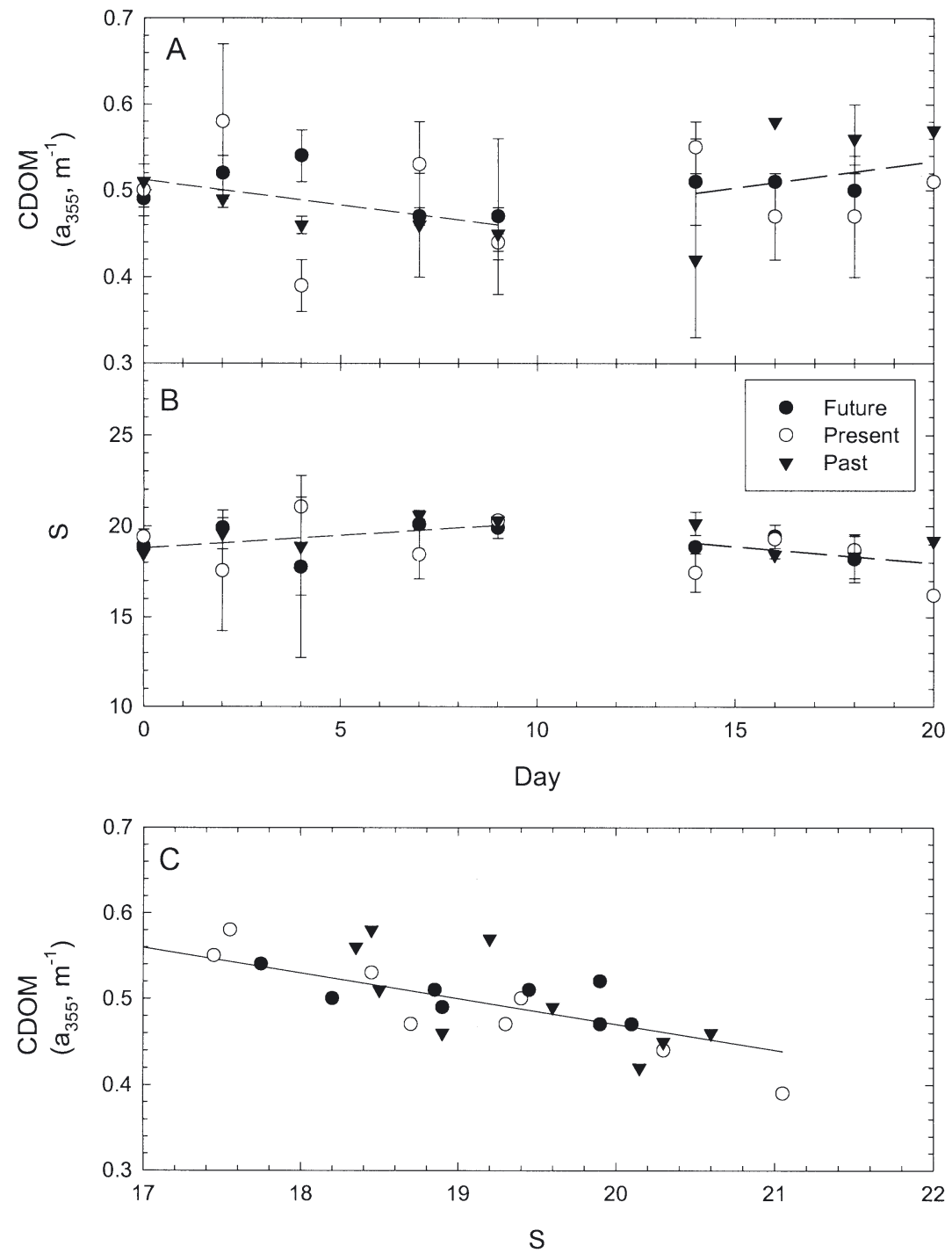

Fig. 3. Absorption of chromophoric dissolved organic matter (CDOM) at a wavelength of $355 \mathrm{~nm}\left(\mathrm{a}_{355}\right)(\mathrm{A})$ and the spectral slope $(S)(\mathrm{B})$ in the 3 treatments, and the relationship between a(355); $\mathrm{m}^{-1}$ and the spectral slope, $S\left(\mathrm{C}_{i}\right.$ $\left.r^{2}=0.63, p<0.05\right)$. In $(A)$ and $(B)$, dashed lines indicate the trends $(p>0.05)$ of the entire data set, split into pre- and post-Day 14. See Fig. 1 legend for details

ments. This lack of difference in terms of DOM concentration and quality may also explain the relatively similar CDOM absorption and $S$-parameter values when the mesocosms are compared. CDOM is part of the bulk DOM pool, and as there were no differences in DOM between treatments it is not surprising that there were no clear treatment effects in terms of CDOM absorption.

The biological sources and sinks of CDOM are still poorly known. In a recent investigation into the role of phytoplankton in the production of CDOM, Rochelle-Newall \& Fisher (2002a) proposed that it is unlikely that CDOM is produced directly by phytoplankton, but that bacteria play an important role in the production of CDOM through alteration of DOM of algal origin. In their examination of the potential role of phytoplankton in the production of CDOM, Rochelle-Newall \& Fisher (2002a) examined the lysis products of eleven algal species from 4 algal classes, and failed to find significant production of CDOM in any of these cultures. Similarly, in the work presented here, CDOM absorption and Emiliania huxleyi abundance were not significantly correlated, although both CDOM and E. huxleyi abundance both increased during the latter part of the experiment (Days 14 to 21). Neither was there a strong link between CDOM concentration and Synechococcus abundance. The picocyanobacterial bloom was probably virally terminated as the increases in viral abundance cooccurred with the decreases in pico-

in CDOM absorption. Although it is possible that there were differences between bacterial populations in the treatments, this does not seem to have affected the bulk DOC concentration, nor the ability of the bacteria to grow on that DOC, as inferred from the relatively similar DOC concentrations in the mesocosms. Neither bacterial production nor bacterial community composition were measured during this experiment, and so it is difficult to determine whether or not there were differences in the bioavailabilty of DOM between treatments. Nevertheless, the lack of difference between mono- and polysaccharides and TEP concentrations in the mesocosms (Engel et al. 2004) points towards a relatively constant DOM composition between treat- cyanobacterial abundance. Moreover, Larsen et al. (2004) have suggested that viruses attack picocyanobacteria in the Raunefjorden, where our experiment took place. However, the high viral abundances observed on Days 11 and 12, several days after the collapse of the picocyanobacterial bloom (Days 7 to 11), suggest that there were also other hosts for the viruses, such as bacteria or other phytoplankton (Larsen et al. 2001). It is difficult to determine whether picocyanobacteria do not release CDOM or its precursors, or whether their cellular biomass was not high enough to detect their contribution to the CDOM pool. Recently, Balch et al. (2002) have proposed that viruses play a role in the production of CDOM through the 
lysis of bacterial cells and the subsequent release of CDOM into the water column. This process did not appear to be the case in the mesocosms, as CDOM absorption was decreasing towards the end of the picocyanobacterial bloom, and not increasing, as would have been expected if viral lysis of the picocyanobacteria were a major source of CDOM in these mesocosms.

The slope of the absorption curve $(S)$ tends to increase with increasing salinity in estuaries (RochelleNewall \& Fisher 2002b); the values presented here are within the range reported for Chesapeake Bay and the adjacent coastal zone, and are also similar to those reported by Stedmon et al. (2000). In this experiment, $S$ initially increased and then began to decrease after the middle point of the experiment. Although CDOM is often considered refractory to bacterial attack (Blough \& Del Vecchio 2002), the decreases in CDOM during the first half of the experiment may indicate that there was a sink of CDOM that was not entirely balanced by new inputs, and that this situation switched to one where the sources of CDOM became more important, relative to the sinks, in the second half of the experiment when CDOM began to accumulate. Indeed, these results suggest that the CDOM pool should be viewed in the same fashion as the DOC pool. In other words, it should be viewed in terms of a 'continuum of lability', combining a background refractory pool with a more dynamic, semi-labile or labile pool (Carlson et al. 1994), rather than as one non-labile pool. The change in direction of the trends of CDOM and $S$ cooccurred with the transition period between the picocyanobacterial bloom and the Emiliania huxleyi bloom, and may provide evidence of 2 pools of CDOM. The first pool, with a higher $S$, is potentially comprised of a combination of background refractory CDOM, overlain with small amounts of 'new' CDOM originating from release from picocyanobacteria or other microflagellates during active growth. The second pool, appearing in the second part of the experiment, has a lower $S$, and potentially consists of the same background refractory CDOM pool supplemented with 'new' CDOM originating from an alternative source, such as E. huxleyi or from the diagenetic alteration of the DOM already present. The positive correlation between absorption and $S$ also supports the hypothesis of different pools of CDOM (Fig. 3C). If the CDOM released had the same ratio of absorption when low and high wavelengths were compared, $S$ would not change, only absorption would increase. However, this is not the case as $S$ does change during the experiment. Indeed, in the second half of the experiment, despite an increase in absorption, $S$ decreased, which may be an indication of a change in the source of the CDOM. Decreases in $S$ are due to an increase in absorption at longer wavelengths and the lower $S$ values may be indicative of CDOM of terrestrial origin or, alternatively, as these were enclosure experiments, of a more diagenetically altered CDOM. However, the fact that the decrease in CDOM absorption also coincides with the termination of the picocyanobacterial bloom may provide evidence for the production of a pool of labile CDOM produced from picocyanobacteria during active growth. This labile pool was then depleted after the removal of the picocyanobacteria from the water column. Regardless of the sources and sinks of CDOM in these mesocosms, it is clear from these results that the timescales of accumulation of CDOM in a natural planktonic assemblage are relatively long, on the order of days to weeks, similar to what has been previously observed in mesocosms (Rochelle-Newall et al. 1999).

The lack of correlation between BA and CDOM is in contrast to the results of several other workers (Nelson et al. 1998, Rochelle-Newall et al. 1999, RochelleNewall \& Fisher 2002a), and may be due to the physical removal of the bacteria from the water column rather than lack of CDOM production by bacteria. The decrease in bacterial abundance occurred concomitantly with a large increase in transparent exopolymeric particle (TEP) concentration (Engel et al. 2004), and it is probable that the bacteria were captured in the TEP and sank down to the bottom of the mesocosms where they were not sampled. The decreases in CDOM absorption up to Day 14 may also have been due to a passive removal mechanism of CDOM from the water column, through either passive inclusion within the TEP or through coagulation and formation of the TEP matrix (Passow 2002, X. Mari pers. comm.).

As with most mesocosm experiments, the relevance of these results to the real environment is difficult to assess. These were relatively closed systems with covers, although the covers did allow transmission of $95 \%$ of the ultraviolet and visible light spectra. However, if we consider that these results can give us some insight into the possible effects of increased $\mathrm{pCO}_{2}$ on the biological production of CDOM, it appears that there will be little increase in CDOM absorption within Emiliania huxleyi blooms, although we cannot rule out that there may be other ecological consequences not examined in this work.

Acknowledgements. Access to installations from the University of Bergen has been funded by the Improving Human Potential Programme from the European Union through Contract No. HPRI-CT-1999-00056 'Bergen Marine' (to U.R.). The participation of J.P.G. and E.R.N. was also funded by the European Union in the framework of the EUROTROPH project (Contract \# EVK3-CT-2000-00040) and CNRS postdoctoral funding to E.R.N. S.J. was funded by a Marie Curie post-doctoral fellowship. M.F. is a senior research associate of the FNRS. 


\section{LITERATURE CITED}

Arrigo RA, Brown CW (1996) Impact of chromophoric dissolved organic matter on UV inhibition of primary productivity in the sea. Mar Ecol Prog Ser 140:207-216

Balch WM, Vaughn J, Novotny J, Drapeau DT and 5 others (2002) Fundamental changes in light scattering associated with infection of marine bacteria by bacteriophage. Limnol Oceanogr 47:1554-1561

Blough NV, Del Vecchio R (2002) Chromophoric dissolved organic matter in the coastal environment. In: Hansell D, Carlson CA (eds) Biogeochemistry of marine dissolved organic matter. Academic Press, New York

Carlson CA, Ducklow HW, Michaels AF (1994) Annual flux of dissolved organic carbon from the euphotic zone in the northwestern Sargasso Sea. Nature 371:405-408

Egge JK, Heimdal BR (1994) Blooms of phytoplankton including Emiliania huxleyi (Haptophyta). Effects of nutrient supply in different N:P ratios. Sarsia 79:333-348

Engel A, Delille B, Jacquet J, Riebesell U, Rochelle-Newall E, Terbrüggen A, Zondervan I (2004) TEP and DOC production during a bloom experiment with Emiliana huxleyi exposed to different $\mathrm{CO}_{2}$ concentration. Aquat Microb Ecol 34:93-104

Gattuso JP, Allemand D, Frankignoulle M (1999) Photosynthesis and calcification at cellular, organismal and community levels in coral reefs: a review on interactions and control by carbonate chemistry. Am Zool 39:160-183

Hein M, Sand-Jensen K (1997) $\mathrm{CO}_{2}$ increases oceanic primary production. Nature 388:526-527

IPCC (Intergovernmental Panel on Climate Change) (2001) Climate change 2001: the scientific basis. Contribution of Working Group I to the third assessment report of the IPCC. Cambridge University Press, Cambridge

Jacquet S, Heldal M, Iglesias-Rodriguez D, Larsen A, Wilson W, Bratbak G (2002) Flow cytometric analysis of an Emiliana huxleyi bloom terminated by viral infection. Aquat Microb Ecol 27:111-124

Larsen A, Castberg T, Sandaa RA, Brussaard CPD and 6 others (2001) Population dynamics and diversity of phytoplankton, bacteria and viruses in a seawater enclosure. Mar Ecol Prog Ser 221:47-57

Larsen A, Flaten GAF, Sandaa RA, Castberg T, Thyrhaug R,

Editorial responsibility: Otto Kinne (Editor),

Oldendorf/Luhe, Germany
Erga SR, Jacquet S, Bratbak G (2004) Spring phytoplankton bloom in Norwegian coastal waters: microbial community succession and diversity. Limnol Oceanogr 49:180-190

Milliman JD, Droxler AW (1996) Neritic and pelagic carbonate sedimentation in the marine environment: ignorance is not bliss. Geol Rund 85:496-504

Nelson NB, Seigel DA, Michaels AF (1998) Seasonal dynamics of colored dissolved organic matter in the Sargasso Sea. Deep-Sea Res I 45:931-957

Passow U (2002) Transparent exopolymer particles (TEP) in aquatic environments. Prog Oceanogr 55:287-333

Porter KG, Feig TS (1980) The use of DAPI for identifying and counting aquatic microflora. Limnol Oceanogr 25:943-948

Riebesell U, Zondervan I, Rost B, Tortell PD, Morel FMM (2000) Reduced calcification of marine plankton in response to increased atmospheric $\mathrm{CO}_{2}$. Nature 407: 364-367

Robertson JE, Robinson C, Turner DR, Holligan P, Watson AJ, Boyd P, Fernandez E, Finch M (1994) The impact of a coccolithophore bloom on oceanic carbon uptake in the northeast Atlantic during summer 1991. Deep-Sea Res I 41:297-314

Rochelle-Newall EJ, Fisher TR (2002a) An investigation into phytoplankton as a source of chromophoric dissolved organic matter. Mar Chem 77:7-21

Rochelle-Newall EJ, Fisher TR (2002b) Chromophoric dissolved organic matter and dissolved organic carbon in Chesapeake Bay. Mar Chem 77:23-41

Rochelle-Newall EJ, Fisher TR, Fan CL, Glibert PM (1999) Dynamics of chromophoric dissolved organic matter and dissolved organic carbon in experimental mesocosms. Int J Remote Sens 20:627-641

Stedmon CA, Markager S, Kaas H (2000) Optical properties and signatures of Chromophoric Dissolved Organic Matter (CDOM) in Danish coastal waters. Estuar Coast Shelf Sci 51:267-278

Vaulot D (1989) CytoPC: processing software for flow cytometric data. Signal Noise 2:8

Williamson CE, Stemberger RS, Morris DP, Frost TM, Paulsen SG (1996) Ultraviolet radiation in North American lakes: attenuation estimates from DOM measurements and implications for plankton communities. Limnol Oceanogr 41:1024-1034

Submitted: August 5, 2003; Accepted: February 12, 2004 Proofs received from author(s): April 15, 2004 